mental to the laboring interest of the community and subversive to every principle of equality."

When the Navy Department asked Baldwin to explain his action, he replied that on any job under his charge he always worked for the best interests of his employer. Under the present circumstances he had discovered that money could be saved for the government through the employment of negroes as stone cutters. At the time of the complaint the negroes on the job were being paid seventy-two cents a day; whereas the white stone cutters demanded a wage ranging from one dollar and fifty cents to two dollars. Moreover, he writes, the bounty of ten cents paid the negroes by the masters served as a powerful incentive. "They work with as much steadiness and cheerfulness as the whites, and the fear of losing their ten cents, if they are lazy or inattentive, saves all the expense of overseers." Baldwin also reported that the negroes were physically better suited for the task than the white workers. Nor did he fail to show his non-Southern origin. As a final justification for his experiment, he advanced the thought, "It is important to this state, where slaves constitute so great a portion of the laborers, that Virginians should learn how the blacks may be made so much more valuable than has been hitherto thought."

The Navy Department was satisfied with Baldwin's explanation and approved the use of slaves on the works. However, the white laborers were not pacified, and a year later an anonymous letter was sent to the President of the United States presenting similar grievances. At a still later date a petition was presented to Congress, dealing with the same controversy. What stir these continued remonstrances produced in Washington, and what action, if any, the Navy Department took, no direct data at present available indicate; but the presentation of the petition some time after the protest and anonymous letter implies that Baldwin was allowed to proceed as he wished.

\title{
In Attemoriam
}

Through the death of Edward Perkins Brown of Boston last month, the Society loses a charter member who has been an enthusiastic supporter of the project since its inception. At the time of his death, Mr. Brown was chairman of the United Shoe Machinery Corporation, president of the board of trustees of the New 
England Conservatory of Music, and director of numerous corporations.

Mr. Brown was born in St. Albans, Vermont, in I 868. Early in his life he moved with his parents to Boston, where he attended the Boston English High School. For several years after being graduated from high school, he worked at numerous occupations in the western part of the country. In I 900 he returned to Boston to become head of the metallic department of the United Shoe Machinery Corporation. He moved up through several positions until in 1917 he became president of the company. Ten years later he was made chairman of the board of the corporation.

Throughout life, Mr. Brown had a special interest in boys. He was a member of the board of overseers of the Boys Club of Boston and a director of tbe Boys Club Federation of Boston. He was also a member of the board of overseers of Boston University and a trustee of the English High School Association.

Mr. Brown was a director of the following companies: British United Shoe Company, Ltd., the Central Aguirre Sugar Company, O. A. Miller Treeing Machine Company, J. C. Rhodes and Company, Old Colony Trust Company, S. A. Felton and Son Company, S. O. and C. Company, Turner Tanning Company, United Shoe Machinery Company de France, Boston Blacking Company, Boston Mutual Life Insurance Company, the First National Bank of Boston, and the Herald-Traveler Corporation.

Mr. Brown's membership in the Society has been characterized throughout by his generous coöperation in furthering the interests of the group.

\section{Secretary's Column}

Since the publication of the last Bulletin the Society has received and gratefully acknowledges the following acquisitions:

From American Optical Company, Southbridge, Massachusetts: six framed action photographs of the manufacturing processes used in making lenses.

From American Petroleum Institute, New York City: Proceedings of the Fourteenth Annual Meeting of the American Petroleum Institute.

From American Steel \& Wire Company, Chicago: twenty-one action photographs of major mechanical operations carried on in the plants of the American Steel \& Wire Company. 